\title{
MAIN ENVIRONMENTAL FACTORS AFFECTING CONCENTRATIONS OF CULTURABLE AIRBORNE BACTERIA IN INDOOR LABORATORIES OVER A PERIOD OF ONE YEAR
}

\author{
HwANG, S. H. ${ }^{1}-$ YoON, C. S..$^{2 *}$ \\ ${ }^{I}$ National Cancer Control Institute, National Cancer Center, 323 Ilsan-ro, Ilsandong-gu, \\ Goyang-si Gyeonggi-do, South Korea \\ ${ }^{2}$ Institute of Health and Environment, School of Public Health, Seoul National University, \\ Gwanak-gu, 1 Gwanak-ro, Seoul, South Korea \\ *Corresponding author \\ e-mail: csyoon@snu.ac.kr \\ tel: +82-2-880-2734; fax: +82-2-745-9104 \\ (Received $18^{\text {th }}$ Aug 2016; accepted $10^{\text {th }}$ Nov 2016)
}

\begin{abstract}
This study aimed to assess temporal changes in the concentration of culturable airborne bacteria $(\mathrm{CAB})$ in three microbiology laboratories to determine the environmental factors that affects $\mathrm{CAB}$ concentration. The $\mathrm{CAB}$ concentration was determined once per month from March 2011 to February 2012 in the three laboratories. An Andersen one-stage sampler was used to collect CAB for $5 \mathrm{~min}$, three times per day. $\mathrm{CAB}$ concentrations demonstrated an increasing tendency in summer and fall, but it was difficult to detect consistent seasonal patterns. Temperature, relative humidity (RH), number of people, and activity of people were associated with $\mathrm{CAB}$ concentrations. The overall $\mathrm{CAB}$ concentrations were significantly greater in the study rooms than that in the laboratory. $\mathrm{CAB}$ concentrations in indoor microbiology laboratories varied greatly depending on the number of people and whether or not a humidifier was used.
\end{abstract}

Keywords: airborne bacteria, temperature, relative humidity, humidifier, seasonality

\section{Introduction}

Air quality in closed environments is an important factor for human health because people tend to spend most of their time in various indoor environments, such as the home, the workplace, or other microenvironments (Klepeis et al., 2001). Exposure to indoor microbial airborne particles, especially fine $(<1 \mathrm{~mm})$ and ultrafine $(<0.1 \mathrm{~mm})$ particles, has been identified as an important factor affecting human health, and is known to cause adverse pulmonary effects, headache, and allergies (Douwes et al., 2003; Dockery, 2009). Airborne bacteria are known to cause infectious diseases, hypersensitivity pneumonitis, and lung functions (Pastuszka et al., 2000).

People who work with microbes or in the field of biotechnology have greater potential to be directly exposed to microorganisms than those in other occupations. Most currently operating clinical microbiology laboratories are busy and crowded. They were often designed several decades ago, before molecular diagnostic methods or bioterrorism preparedness became commonplace. Their air-handling systems have become overloaded or unstable as instruments and personnel have multiplied (Baron and Miller, 2008). Characterization and measurement of the concentration of airborne microorganisms in a laboratory is difficult because of the diversity of infectious microorganisms handled, variation in the efficiencies of air 
sampling equipment, differences in the viability of infectious microorganisms, and lack of a standardized method for measuring individual microorganisms in the air (Hwang et al., 2014a). Many positive changes have been made in standard safety practices, and most laboratory workers feel that they are safer than they were earlier, but evidencebased research is lacking to confirm that supposition. Therefore, maintenance of a sanitary environment is crucial for laboratories dealing with microorganisms.

The purpose of this study was to assess temporal changes in CAB concentrations in three microbiology laboratories to determine which environmental factors, such as temperature, relative humidity $(\mathrm{RH})$, number of people, and activity of people, are associated with CAB concentrations.

\section{Materials and methods}

\section{Characteristics of the laboratories and environmental factors}

This study was conducted for a 12-month period from March 2011 to February 2012. A total of 212 samples were collected once a month in the three microbial laboratories. Table 1 summarizes the characteristics of the laboratories. The environmental factors such as temperature, $\mathrm{RH}$, Number of people, and activity of people were measured in the three microbial laboratories. Temperature and $\mathrm{RH}$ were recorded by VelociCalc Air Velocity Meter (Model 9555, TSI Inc., USA). Number of people was counted only during CAB sampling times and activity of people was measured by counting of people who were passing by the sampling site within one meter during $\mathrm{CAB}$ sampling times.

\section{Sampling and analysis}

CAB was collected three times a day (9:00-10:00, 13:00 - 14:00, and 16:00- 17:00), for once a month in each laboratory. Every sampling was conducted at the same location: the center of the each room. A single-stage viable cascade impactor (SKC Inc., USA) connected with a pump (Quick Take 30, SKC Inc., USA) was operated at a flow rate of $28.31 \mathrm{~min}^{-1}$ for $5 \mathrm{~min}$. Before the sampling operation, the sampling equipment was sterilized with a $70 \%$ ethyl alcohol swab, and nutrient media in Petri dishes were placed on the one-stage impactor. The $\mathrm{CAB}$ samples were collected on trypicase soy agar (TSA) plates. The sampled media were sealed with laboratory film to prevent contamination and desiccation during the incubation. The samples were transferred to the laboratory in a sterilized ice box with refrigerant packs to keep the samples below $4^{\circ} \mathrm{C}$. TSA plates were incubated at $35^{\circ} \mathrm{C}$ for up to 2 days. The positive hole correction table was used to adjust colony counts (ACGIH, 1999). The concentrations of CAB was calculated by dividing the number of colonies by air volume and written as colonyforming unit per cubic meter of air $\left(\mathrm{CFUm}^{-3}\right)$.

\section{Statistical analysis}

Kolmogorov-Smirnov test was used to determine whether the data were normally or log-normally distributed. Arithmetic means (AM) of CAB concentrations and their standard deviation (SD) were calculated. Independent $t$-test was used to compare the differences between environmental factors such as divided room by structure of laboratory, use of humidifier, and use of air-conditioner. CAB concentrations in the three microbial laboratories, and $\mathrm{p}$ value less than 0.05 was considered to be statistically 
significant. Correlation analysis was used to identify the association between $\mathrm{CAB}$ concentrations and environmental factors. All statistical analyses were performed by SPSS (version 23.0; IBM Inc., USA).

\section{Results}

Table 2 summarizes the $\mathrm{CAB}$ concentrations in the three microbiology laboratories each month. The $\mathrm{AM}$ of $\mathrm{CAB}$ concentrations over the year ranged from 7-5823 $\mathrm{CFUm}^{-3}$ in the three microbiology laboratories. The highest AM concentration of CAB was found in August for laboratories A $\left(945 \mathrm{CFUm}^{-3}\right.$ ) and $\mathrm{B}\left(1162 \mathrm{CFUm}^{-3}\right)$ and in October in laboratory C $\left(2396 \mathrm{CFUm}^{-3}\right)$, whereas the lowest AM concentration of CAB was observed in February in laboratory A (60 $\mathrm{CFUm}^{-3}$ ), in March in laboratory B $\left(91 \mathrm{CFUm}^{-3}\right)$, and April in laboratory $\mathrm{C}$ (319 $\left.\mathrm{CFUm}^{-3}\right)$. The $\mathrm{AM}$ of $\mathrm{CAB}$ concentrations differed significantly between laboratories $\mathrm{A}$ and $\mathrm{B}$ and $\mathrm{C}(\mathrm{p}<0.05)$.

To show seasonal changes in $\mathrm{CAB}$ concentrations, the 12 months were grouped into four seasons: March to May were grouped as spring, June to August as summer, September to November as fall, and December to February as winter. Figure 1 presents seasonal changes in $\mathrm{CAB}$ concentrations. Laboratories A and B showed similar seasonal changes in $\mathrm{CAB}$ concentrations, gradually increasing from summer to fall and then decreasing from fall to winter. However, the $\mathrm{CAB}$ concentrations in laboratory $\mathrm{C}$ increased from fall to winter and decreased from spring to summer.

Spearman correlation analyses were performed to identify relationships between $\mathrm{CAB}$ concentrations, temperature, $\mathrm{RH}$, number of people, and activity (Table 3). A significant positive correlation was observed between $\mathrm{CAB}$ concentration and temperature $(\mathrm{r}=0.269, \mathrm{p}<0.001), \mathrm{RH}(\mathrm{r}=0.451, \mathrm{p}<0.001)$, number of people $(\mathrm{r}=$ $0.328, \mathrm{p}<0.001)$, and activity of people $(0.321, \mathrm{p}<0.001)$.

Table 4 shows the $\mathrm{CAB}$ concentrations by location and by factors within laboratories. Two groups were defined for each factor, as follows: laboratory rooms and study rooms, off and on for the humidifier, laboratory room and study room among rooms with the humidifier off, off and on for the air conditioner. The CAB concentrations were significantly higher in study rooms than in laboratory rooms; they were significantly higher in the laboratories in which the humidifier was on than in laboratories in which the humidifier was off; when the humidifier was on, they were higher in study rooms than in laboratories; they were higher in the laboratories in which the air conditioner was on than in the laboratories in which it was off. However, no significant difference in $\mathrm{CAB}$ concentrations was observed between groups when the humidifier was off or when the air-conditioner was on ( $p>0.05)$.

Fig. 2 shows associations between $\mathrm{CAB}$ concentrations and number of people in each study room. $\mathrm{CAB}$ concentrations in laboratory $\mathrm{C}(\mathrm{r}=0.451)$, which contained more people, were significantly more strongly associated with number of people than those of laboratories $\mathrm{A}$ or $\mathrm{B}$, although $\mathrm{CAB}$ concentrations in laboratories $\mathrm{A}(\mathrm{r}=0.137)$ and $B(r=0.331)$ were also associated with number of people. 
Table 1. The characteristics of environmental factors in the three microbial laboratories

\begin{tabular}{|c|c|c|c|}
\hline & Laboratory A & Laboratory B & Laboratory C \\
\hline Room volume $\left(\mathrm{m}^{-3}\right)$ & 380 & 393 & 390 \\
\hline (Area $\times$ Height $)$ & $(146 \times 2.6)$ & $(151 \times 2.6)$ & $61.4(151 \times 2.6)$ \\
\hline \multicolumn{4}{|l|}{ Temperature $\left({ }^{\circ} \mathrm{C}\right)$} \\
\hline$($ Mean $\pm \mathrm{SD})$ & $23.6 \pm 2.4$ & $24.2 \pm 2.5$ & $24.5 \pm 1.4$ \\
\hline \multicolumn{4}{|l|}{$\mathrm{RH}(\%)$} \\
\hline$($ Mean \pm SD $)$ & $37.7 \pm 20.5$ & $34.3 \pm 18.3$ & $35.7 \pm 18.2$ \\
\hline $\begin{array}{l}\text { No. of people } \\
(\text { Mean } \pm \text { SD) }\end{array}$ & $0.98 \pm 1.38$ & $1.10 \pm 1.56$ & $2.90 \pm 3.40$ \\
\hline Laboratory room & $0.4 \pm 0.6$ & $0.4 \pm 0.6$ & $0.8 \pm 0.70$ \\
\hline Study room & $1.6 \pm 1.7$ & $1.8 \pm 1.9$ & $5.0 \pm 1.25$ \\
\hline \multicolumn{4}{|l|}{ Activity of people } \\
\hline$($ Mean $\pm \mathrm{SD})$ & $1.00 \pm 1.30$ & $0.84 \pm 1.31$ & $1.46 \pm 1.67$ \\
\hline Experiment & $\begin{array}{l}\text { Production of amino acid with } \\
\text { microorganism }\end{array}$ & $\begin{array}{l}\text { Production of amino acid } \\
\text { with microorganism }\end{array}$ & $\begin{array}{l}\text { Waste purification } \\
\text { with microorganism }\end{array}$ \\
\hline
\end{tabular}


Table 2. Monthly concentrations of CAB in three microbial laboratories

\begin{tabular}{|c|c|c|c|c|c|c|c|c|c|}
\hline \multirow[t]{3}{*}{ Months } & \multicolumn{9}{|c|}{$\mathrm{CAB}\left(\mathrm{CFUm}^{-3}\right)$} \\
\hline & \multicolumn{3}{|c|}{ Lab. A } & \multicolumn{3}{|c|}{ Lab. B } & \multicolumn{2}{|r|}{ Lab. C } & \\
\hline & $\mathrm{N}$ & Mean(SD) & Range & $\mathrm{N}$ & Mean(SD) & Range & $\mathrm{N}$ & Mean(SD) & Range \\
\hline Jan. & 6 & $107(55.6)$ & $50-213$ & 6 & $120(112.1)$ & $28-329$ & 6 & $1780(2434.0)$ & $108-5823$ \\
\hline Feb. & 6 & $126(117.2)$ & $7-337$ & 6 & $122(112.5)$ & $35-346$ & 6 & $594(383.2)$ & $190-1175$ \\
\hline Mar. & 5 & $60(32.4)$ & $21-101$ & 6 & $91(44.6)$ & $35-130$ & 5 & $1191(1158.2)$ & $290-2572$ \\
\hline Apr. & 6 & $335(165.4)$ & $138-543$ & 6 & $110(94.1)$ & $28-251$ & 6 & $319(159.2)$ & $86-587$ \\
\hline May & 6 & $273(235.3)$ & $115-729$ & 6 & $241(167.2)$ & $64-435$ & 6 & $375(238.4)$ & $175-842$ \\
\hline Jun. & 6 & $576(293.4)$ & $213-988$ & 6 & $485(183.4)$ & $314-823$ & 6 & $767(490.5)$ & $167-1317$ \\
\hline Jul. & 6 & $387(187.5)$ & $220-693$ & 6 & $507(163.6)$ & $329-712$ & 6 & $623(360.2)$ & $220-1273$ \\
\hline Aug. & 6 & 945 (1117.7) & $190-3177$ & 6 & $1162(896.1)$ & $451-2888$ & 6 & $641(373.1)$ & $71-1196$ \\
\hline Sept. & 4 & $510(59.7)$ & $451-570$ & 6 & 290 (199.6) & $93-596$ & 6 & $706(211.1)$ & $329-968$ \\
\hline Oct. & 6 & 748 (1210.5) & $64-3177$ & 6 & $206(73.3)$ & $86-314$ & 6 & $2396(2013.6)$ & $306-5180$ \\
\hline Nov. & 6 & $630(661.0)$ & $130-1931$ & 6 & $210(68.0)$ & $123-298$ & 6 & $517(166.1)$ & $306-739$ \\
\hline Dec. & 6 & $91(44.2)$ & $42-153$ & 6 & $290(151.4)$ & $115-493$ & 6 & 1133 (1369.2) & $259-3754$ \\
\hline Total & 69 & $401(571.3)$ & $7-3177$ & 72 & $320(391.5)$ & $28-2888$ & 71 & $916(1157.6)$ & $71-5823$ \\
\hline
\end{tabular}


Table 3. Spearman correlation analysis between $C A B$ and environmental factors in the microbial laboratories

\begin{tabular}{|c|c|c|c|c|c|}
\hline & Conc. $\left(\mathrm{CFUm}^{-3}\right)$ & Temperature $\left({ }^{\circ} \mathrm{C}\right)$ & $\mathrm{RH}(\%)$ & No. of people & Activity of people \\
\hline Conc. $\left(\mathrm{CFUm}^{-3}\right)$ & 1.000 & & & & \\
\hline Temperature $\left({ }^{\circ} \mathrm{C}\right)$ & $0.269^{* * *}$ & 1.000 & & & \\
\hline $\mathrm{RH}\left({ }^{\circ} \mathrm{C}\right)$ & $0.451^{* *}$ & $0.301^{* *}$ & 1.0000 & & \\
\hline No. of people $(\%)$ & $0.328^{* *}$ & 0.120 & -0.038 & 1.000 & \\
\hline Activity of people & $0.321^{* *}$ & $0.232^{* *}$ & $0.218^{* *}$ & $0.232^{* *}$ & 1.000 \\
\hline
\end{tabular}

*: $p<0.05, * *: p<0.001, N=204$

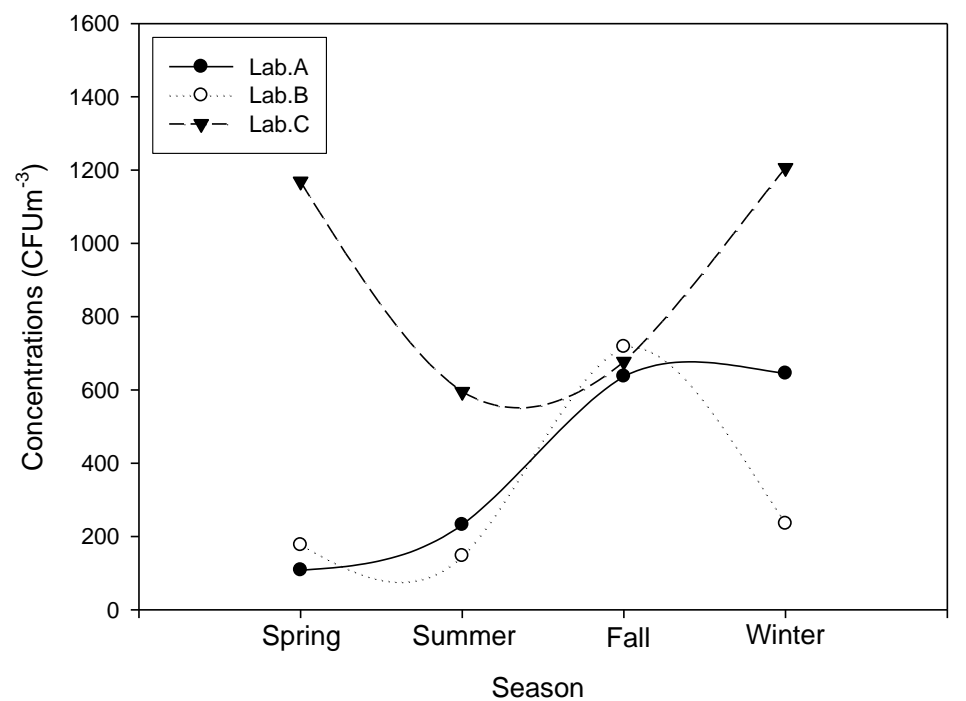

Figure 1. Seasonal changes in concentrations of $C A B$ in microbial laboratories

APPLIED ECOLOGY AND ENVIRONMENTAL RESEARCH 15(1): 321-333. http://www.aloki.hu • ISSN 15891623 (Print) • ISSN 17850037 (Online)

DOI: http://dx.doi.org/10.15666/aeer/1501_321333

(๑) 2017, ALÖKI Kft., Budapest, Hungary 
Table 4. Comparisons of $C A B$ concentrations between the categorized groups by the environmental factors of the three microbial laboratories

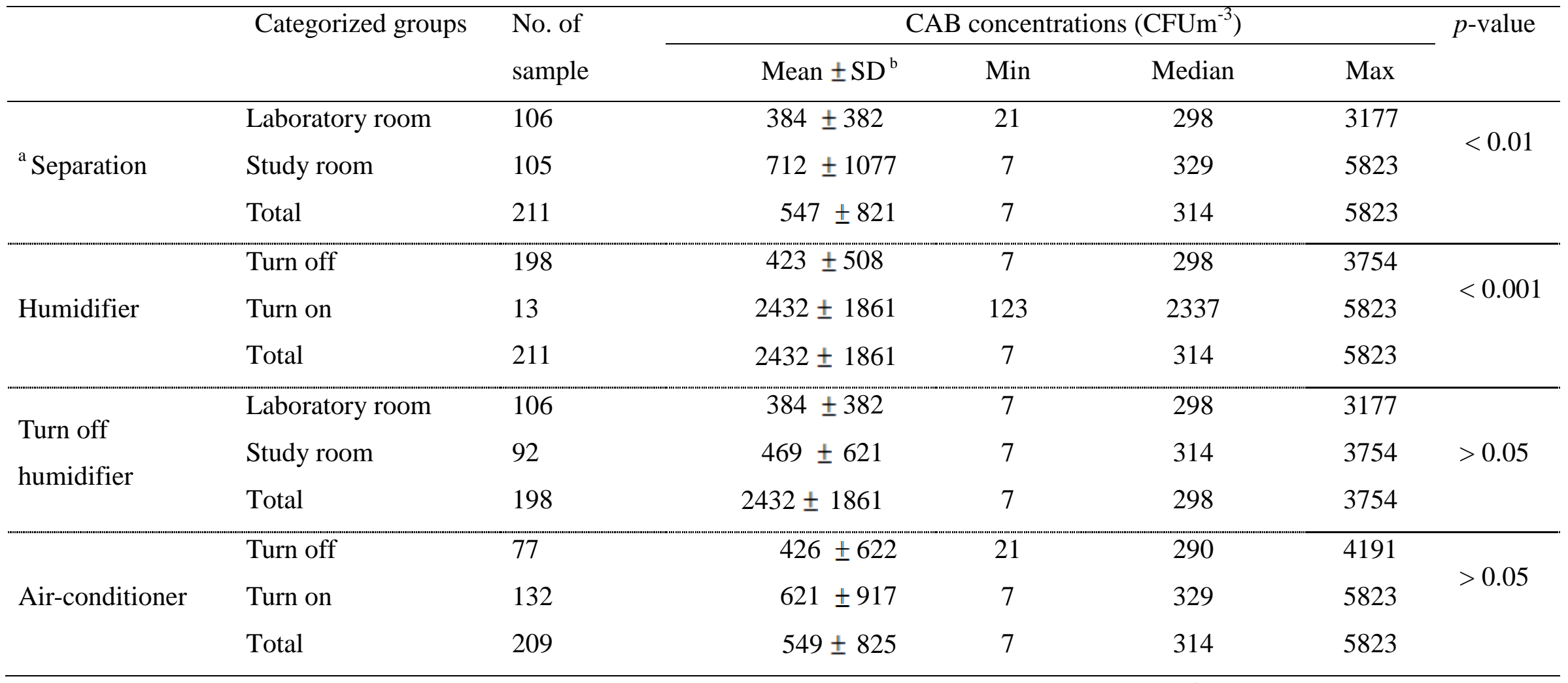

${ }^{\mathrm{a}}$ These laboratories were made up of one space divided by two spaces into laboratory room and study room with a partition wall ${ }^{\mathrm{b}}$; Standard deviation 


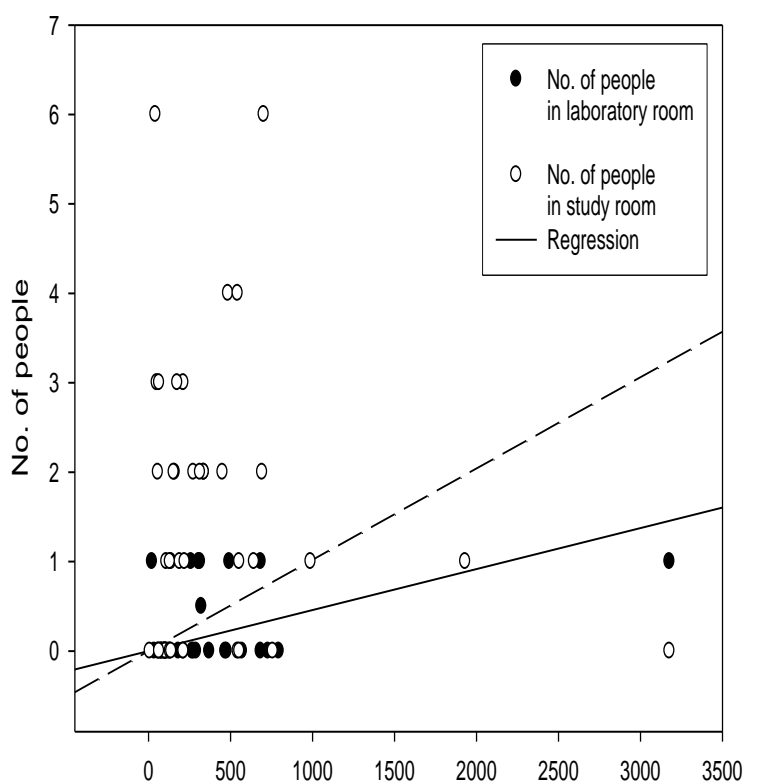

(a) Laboratory A ( $\mathrm{r}=0.137)$

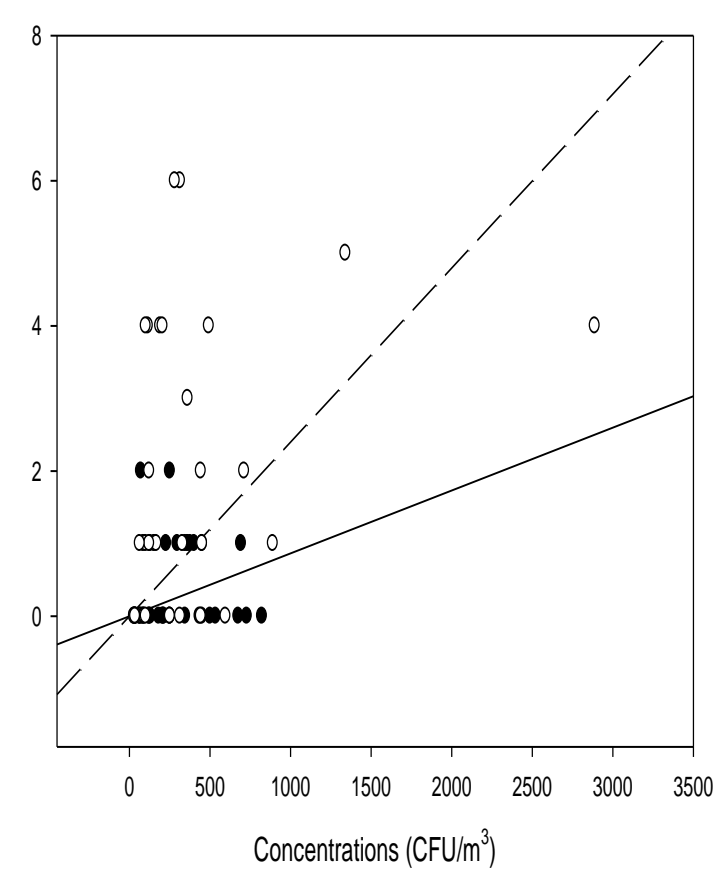

(b) Laboratory B ( $\mathrm{r}=0.331)$

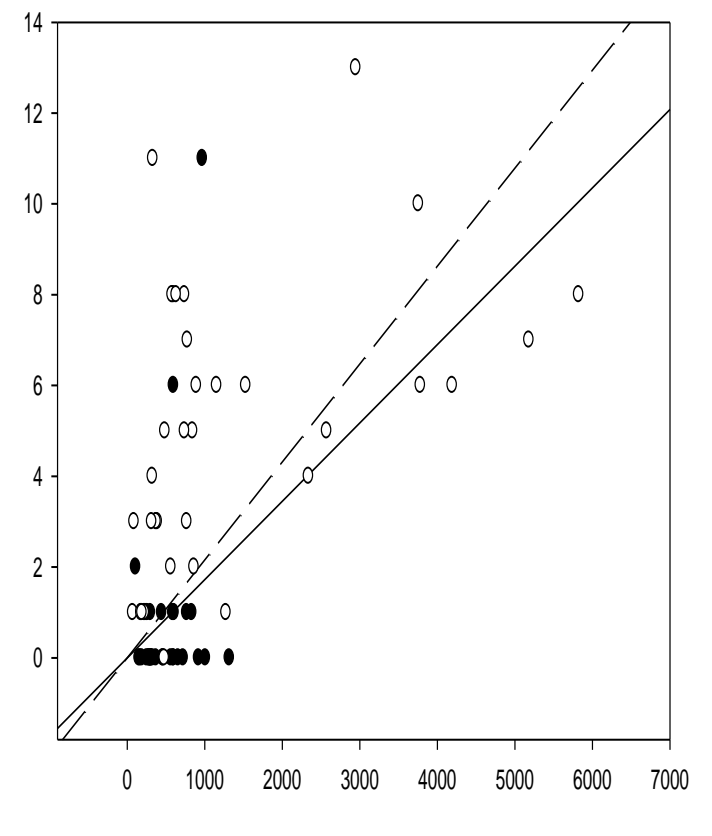

(c) Laboratory C ( $\mathrm{r}=0.451)$

Figure 2. Association between CAB concentrations and the number of people both for laboratory room and study room of laboratory $A$, B, and $C$ 


\section{Discussion}

$\mathrm{CAB}$ concentrations were measured in three microbiology laboratories to assess monthly and seasonal changes and to investigate the effects of several environmental factors (temperature, $\mathrm{RH}$, number of people, and activity of people) to determine whether there are any associations between these factors and $\mathrm{CAB}$ concentrations.

In 29 of a total of 212 samples $(13.7 \%)$ from the three microbiology laboratories, $\mathrm{CAB}$ concentrations exceeded $800 \mathrm{CFUm}^{-3}$, according to Korean guidelines (Ministry of Environment of Korea, 2014). Among the 29 samples that exceeded $800 \mathrm{CFUm}^{-3}, 21$ were from laboratory $\mathrm{C}$. The overall mean concentration $\left(916 \mathrm{CFUm}^{-3}\right)$ of $\mathrm{CAB}$ in laboratory $\mathrm{C}$ was threefold higher than the Indoor Air Quqlity Association recommendation. A previous study showed that the mean concentration of total airborne bacteria in indoor environments, including occupational environments, was $308 \mathrm{CFUm}^{-3}$ in subway stations (Hwang et al., 2015), $684 \mathrm{CFUm}^{-3}$ (median) in homes, $222 \mathrm{CFU} / \mathrm{m}^{-3}$ (median) in elderly car centres (Madureira et al., 2015), $105 \mathrm{CFU} / \mathrm{m}^{-3}$ in swine confinement buildings (Douwes et al., 2003), $113 \mathrm{CFUm}^{-3}$ in a feedstock manufacturing factory (Kim et al., 2007), $198 \mathrm{CFUm}^{-3}$ during a pelleting and powdering process, and $281 \mathrm{CFUm}^{-3}$ (maximum level) in 100 U.S. office buildings (Tsai and Macher, 2005). These concentrations of total airborne bacteria were relatively low compared to that measured in laboratory $\mathrm{C}$ in this study. Airborne bacteria levels exceeding $600 \mathrm{CFUm}^{-3}$ can be associated with insufficient ventilation or abnormal sources of microorganisms (Salonen et al., 2007).

The $\mathrm{CAB}$ concentrations in laboratories $\mathrm{A}$ and $\mathrm{B}$ presented similar seasonal patterns, whereas the $\mathrm{CAB}$ concentrations in laboratory $\mathrm{C}$ showed a contrasting pattern (Fig. 1). In previous studies of indoor air quality conducted in Chicago homes, culturable bacteria were highest in summer and fall (Moschandreas et al., 2003), whereas in Finland, only a slight yet significant difference was observed between summer and winter bacterial levels (Reponen et al., 1992). However, other studies in homes have shown a large decline from spring to summer, an increase in fall, followed by a decrease toward winter (Frankel et al., 2012). These discrepancies might be caused by other factors, which can influence $\mathrm{CAB}$ concentrations, rather than by seasonal changes themselves. Sources of bacteria in outdoor air can change over short periods of time, in relation to climatic conditions (Rintala et al., 2008; Womack et al., 2010); however, indoor air bacterial concentrations are less strongly related to climatic conditions than those of outdoor air.

To identify factors influencing $\mathrm{CAB}$ concentrations in microbiology laboratories, Spearman's correlation analyses were used to identify correlations between CAB concentrations, temperature, RH, number of people, and activity of people (Table 3). Positive correlations were observed between $\mathrm{CAB}$ concentrations, temperature $(\mathrm{r}=$ $0.269)$, RH $(r=0.451)$, number of people $(r=0.328)$, and activity of people $(r=0.321)$. Temperature is an environmental factor that typically influences biological agents (WHO, 2009). In our study, higher CAB concentrations were significantly related to higher temperature. This result is consistent with previous studies (Guo et al., 2004; Jo et al., 2005; Hwang et al., 2011a; Hwang et al., 2015). However, other studies did not show associations, positive or negative, between $\mathrm{CAB}$ concentrations and temperature (Frankel et al., 2012; Madureira et al., 2015). The authors hypothesized that the 
discrepancy might be caused by small variations in indoor parameters, which exclude any association with biological pollutants. RH was significantly associated with CAB concentrations $(\mathrm{p}<0.05)$ and was the environmental factor most strongly associated with the CAB concentration $(r=0.451)$. RH is known to be crucial for microorganism growth, even at low temperatures (Tsai et al., 2009). However, no relationship was observed between comparatively low $\mathrm{RH}(<60 \%)$ and $\mathrm{CAB}$ concentration (Hwang et al., 2011a). The number of people $(r=0.328)$ and activity of people $(r=0.321)$ were associated with $\mathrm{CAB}$ concentrations. Other studies have found that the number of people is positively associated with the concentration of CABs in subway station environments, consistent with airborne microorganisms being dispersed into the air from subway passengers' clothing and hair (Boudia et al., 2006; Cho et al., 2006; Bogomolova and Kirtsideli, 2009; Hwang et al., 2014b). Moreover, changes in microbial communities between peak and nonpeak commuting hours can largely be attributed to increases in skin-associated genera (Leung et al., 2014). Sources of airborne bacteria in built environments include humans, pets, soils, and plants (Jo and Seo, 2005). Indoor human occupancy was found to be closely related to indoor microbial levels (Scheff et al., 2000), and settled spores were resuspended in indoor air by air movement caused by human activities, such as walking and running (Buttner and Stetzenbach, 1993). In classrooms, sampling time supports the effect of activity, as indoor bioaerosol ratios were higher during break times, when childrens' activity was higher than during class time (Jo and Seo, 2005).

$\mathrm{CAB}$ concentrations were higher in study rooms than in laboratory rooms, even in which the humidifier was turned off (Table 4). These results may be influenced by peoples' activity levels, which could contribute to increased CAB concentrations, as mentioned earlier. Fig. 2 demonstrates that the CAB concentration increased as the number of people increased in three study rooms. Laboratories using a humidifier showed significantly higher concentrations of $\mathrm{CAB}$ than laboratories not using a humidifier. Humidifiers can introduce bacteria into the air, as many spray water, especially those that use recirculated water or water from stagnant indoor reservoirs; Legionella spp. can colonize warm to hot water systems, living in biofilms that develop on surfaces in contact with water (ACGIH, 1999). Higher concentrations of CAB were observed in laboratories with the air conditioner on than in laboratories with the air conditioner off. Ventilation systems affect indoor bioaerosol concentrations because they prevent outdoor microorganisms from being transported inside buildings (Wu et al., 2005). Good ventilation and hygiene decrease the concentrations of airborne contaminants. That is, a higher ventilation rate may lead to decreased exposure to inflammatory microbial components, as measured in a granulocyte assay (Frankel et al., 2012). However, it is well known that indoor facilities such as rooms, hallways, and underground parking lots show poor indoor air quality, and poor ventilation is known to be one of the most important causes of poor air quality (Fisk et al., 2009). In addition, condensation on filters and surfaces within heating, ventilating, and air conditioning systems can be a source of biological contamination (ACGIH, 1999).

Although we identified environmental factors that can affect $\mathrm{CAB}$ concentrations throughout our one-year assessment cycle, this study has several limitations. First, the incubation temperature was high. The optimum temperature range for growth of $\mathrm{CAB}$ is known to be $25-30^{\circ} \mathrm{C}$, but in this study, $\mathrm{CAB}$ were incubated at $35^{\circ} \mathrm{C}$. However, the optimum temperature differs depending on the species (Ayersi, 1969; Pitt et al., 1983). 
Second, because of issues of accessibility, resources, and permits, we were unable to conduct the tests at the three laboratories at the same time. Finally, we were unable to identify the isolated $\mathrm{CAB}$ due to a funding shortage. However, we were able to predict the species of some $\mathrm{CAB}$ based on previous studies conducted in similar indoor microbiology laboratories (Hwang et al., 2011b; 2013).

\section{Conclusion}

We assessed the monthly and seasonal changes in CAB concentrations in three microbiology laboratories and determined which environmental factors, such as temperature, RH, number of people, and activity of people, were associated with $\mathrm{CAB}$ concentrations. $\mathrm{CAB}$ concentrations did not show consistent patterns of seasonal variation between laboratories. Temperature, RH, number of people, and activity of people were associated $\mathrm{CAB}$ concentrations. The overall $\mathrm{CAB}$ concentrations were significantly greater in the study rooms than in the laboratory rooms. $\mathrm{CAB}$ concentrations varied greatly depending on the number of people and use of a humidifier. Therefore, it is important to clean humidifiers regularly to prevent overgrowth of $\mathrm{CAB}$ in indoor environments.

Acknowledgements. This research was supported by Basic Science Research Program through the National Research Foundation of Korean (NRF) funded by the Ministry of Science, ICT \& Future Planning (2015R1C1A1A02037363).

\section{REFERENCES}

[1] American Conference of Governmental Industrial Hygienists (ACGIH) (1999). In: Macher, J., Ammann, H. A. Milton, D. K., Burge, H. A., Morey, P. R. (Eds.) Bioaerosols: Assessment and Control. American Conference of Governmental Industrial Hygienist, Cincinnati, Ohio.

[2] Baron, E.J., Miller, J.M. (2008): Bacterial and fungal infections among diagnostic laboratory workers: evaluating the risks. - Diagnostic Microbiology and Infectious Disease 60: 241-246

[3] Ayersi, G. (1969): The effects of moisture and temperature on growth and spore germination in some fungi. - Journal of Stored Products Research 5(2): 127-141.

[4] Bogomolova, E., Kirtsideli, I. (2009): Airborne fungi in four stations of the St. Petersburg underground railway system. - International Biodeterioration \& Biodegradation 63:156160.

[5] Boudia, N., Halley, R., Kennedy, G., Lambert, J., Gareau, L., Zayed, J. (2006): Manganese concentrations in the air of the Montreal (Canada) subway in relation to surface automobile traffic density. - Science of the Total Environment 366:143-147.

[6] Buttner, M.P., Stetzenbach, L.D. (1993): Monitoring airborne fungal spores in an experimental indoor environment to evaluate sampling methods and the effects of human activity on air sampling. - Applied and Environmental Microbiology 59: 219-226.

[7] Cho, J.H., Min K.H., Paik, N.W. (2006): Temporal variation of airborne fungi concentrations and related factors in subway stations in Seoul, Korea. - International Journal of Hygiene and Environmental Health 209: 249-255.

[8] Dockery, D.W. (2009): Health effects of particulate air pollution. - Annals of Epidemiology 19: 257-263.

[9] Douwes, J., Thome, P., Pearce, N., Heederik, D. (2003): Bioaerosol health effect and 
exposure assessment: Progress and prospects. - Annals of Occupational Hygiene 47(3): 187-200.

[10] Guo, H., Lee, S.C., Chan, L.Y. (2004): Indoor air quality investigation at air-conditioned and non-air conditioned markets in Hong Kong. 2004. - Science of the Total Environment 323:87-98.

[11] Fisk, W.J., Mirer, A.G., Mendell, M.J. (2009): Quantitative relationship of sick building syndrome symptoms with ventilation rates. - Indoor Air 19: 159-165.

[12] Frankel, M., Beko, G., Timm, M., Gustavsen, S., Hansen, E.W., Madsen, A.M. (2012): Seasonal variations of indoor microbial exposures and their relation to temperature, relative humidity, and air exchange rate. - Applied and Environmental Microbiology 78(23):8289-8297.

[13] Hwang, S.H., Lee, I.M., Yoon, C.S. (2013): Levels of total airborne bacteria, gramnegative bacteria, and endot oxin according to biosafety levels in Korean biosafety laboratories. - Human and Ecological Risk Assessment 19(6): 1576-1585.

[14] Hwang, S.H., Park, D.U., Ha, K.C., Cho, H.W., Yoon, C.S. (2011a): Airborne bacteria concentrations and related factors at university laboratories, hospital diagnostic laboratories and a biowaste site. - Journal of Clinical Pathology 64:261-264.

[15] Hwang, S.H., Park, D.U., Joo, S.I., Park, H.H., Yoon, C.S. (2011b): Comparison of endotoxin levels and Gram-negative bacteria under different conditions in microbial laboratories and a biowaste site. - Chemosphere 85: 135-139.

[16] Hwang, S.H., Park, H.H., Yoon, C.S. (2014a): Analysis of variation in total airborne bacteria concentration to assess the performance of biological safety cabinets in microbial laboratories. - Safety and Health at Work 5: 23-26

[17] Hwang, S.H., Park, W.H., Ahn, J.K., Lee, K.J., Min, K.B., Park, J.B. (2015): Relationship between culturable airborne bacteria concentrations and ventilation systems in underground subway stations in Seoul, South Korea. - Air Quality, Atmosphere and Health 9(2):173-178..

[18] Hwang, S.H., Park, J.B. (2014b): Comparison of culturable airborne bacteria and related environmental factors at underground subway stations between 2006 and 2013. Atmospheric Environment 84: 289-293.

[19] Jo, W.K., Seo, Y.J. (2005): Indoor and outdoor bioaerosol levels at recreation facilities, elementary schools, and homes. - Chemosphere 61: 1570-1579.

[20] Klepeis, N.E., Nelson, W.C., Ott, W.R., Robinson, J.P., Tsang, A.M., Switzer, P. (2001): The National Human Activity Pattern Survey (NHAPS): a resource for assessing exposure to environmental pollutants. - Journal of Exposure Analysis and Environmental Epidemiology 11: 231-252.

[21] Kim, K.Y., Jeong, Y.I., Kim, C.N. (2007): Distribution of airborne microorganism in the feedstuff manufacture factory. - Journal of Korea Society Occupational and Environmental Hygiene 17(4):335-42.

[22] Leung, H.Y., Wilkins, D., Li, K.T., Kong, K.F., Lee, K.H. (2014): Indoor-air microbiome in an urban subway network: diversity and dynamics. - Applied and Environmental Microbiology 80:6760-6770.

[23] Madureira, J., Paciencia, I., Rufo, J.C., Pereira, C., Teixeira, J.P., Fernandes, E.O. (2015): Assessment and determinants of airborne bacterial and fungal concentrations in different indoor environments: Homes, child day-care centres, primary schools and elderly care centres. - Atmospheric Environment 109: 139-146.

[24] Moschandreas, D., Pagilla, K.R., Storino, L.V. (2003): Time and space uniformity of indoor bacteria concentrations in Chicago area residences. - Aerosol Science and Technology 37:899-906.

[25] Ministry of Environment of Korea. (2014): Indoor Air quality management in public facilities. - Indoor Air Quality Management Act Amendment.

[26] Pastuszka, J.S., Kyaw Tha Paw, U., Lis, D.O., Wlazlo, A., Ulfig, K. (2000): Bacterial and fungal aerosol in indoor environment in upper silesia, poland. - 
Atmospheric Environment 34(22): 3833-3842.

[27] Pitt, J., Hocking, A.D., Glenn, D.R. (1983): An improved medium for the detection of aspergillus flavus and a. Parasiticus. - Journal of Applied Microbiology 54(1): 109-114.

[28] Reponen, T., Nevalainen, A., Jantunen, M., Pellikka, M., Kalliokoski, P. (1992): Normal range criteria for indoor air bacteria and fungal spores in a subarctic climate. - Indoor Air $2: 26-31$

[29] Rintala, H., Pitkaeranta, M., Toivola, M., Paulin, L., Nevalainen, A. (2008): Diversity and seasonal dynamics of bacterial community in indoor environment. - BMC Microbiology 8:56.

[30] Salonen, H., Lappalainen, S., Lindroos, O., Harju, R., Reijula, K. (2007): Fungi and bacteria in mould-damaged and non-damaged office environments in a subarctic climate. - Atmospheric Environment 41:6797-6807.

[31] Scheff, P.A., Paulius, V.K., Curtis, L., Conroy, L.M. (2000): Indoor air quality in a middle school, Part II: Development of emission factors for particulate matter and bioaerosols. - Applied Occupational and Environmental Hygiene 15: 835-842.

[32] Tsai, F.C., Macher, J.M. (2005): Concentrations of airborne culturable bacteria in 100 large US office buildings from the BASE study. - Indoor Air 15(9):71-81.

[33] Tsai, M.Y., Liu, H.M. (2009): Exposure to culturable airborne bioaerosols during noodle manufacturing in central Taiwan. - Science of the Total Environment 407:1536-1546.

[34] Womack, A.M., Bohannan, B.J.M., Green, J.L. (2010): Biodiversity and biogeography of the atmosphere. - Philosophical Transactions of the Royal Socoety B 365: 3645-3653.

[35] World Health Organization (WHO). (2009): WHO Guidelines for Indoor Air Quality: Dampness and Mould. WHO Regional Office for Europe, Scherfigsvej 8, DK-2100 Copenhagen Ø, Denmark.

[36] Wu, P.O., Li, Y.Y., Chiang, C.M., Huang, C.Y., Lee, C.C., Li, F.C., Su, H.J. (2005): Changing microbial concentrations are associated with ventilation performance in taiwan's air-conditioned office buildings. - Indoor Air 15(1): 19-26. 